\title{
New species of Cetopsidium (Siluriformes: Cetopsidae: Cetopsinae) from the upper rio Branco system in Guyana
}

\author{
Richard P. Vari ${ }^{1}$ and Carl J. Ferraris Jr. ${ }^{2}$
}

Cetopsidium soniae, new species, is described from the Takutu River basin of southwestern Guyana, within the upper portions of the rio Branco of the Amazon basin. The new species differs from its congeners in details of pigmentation, the length of the pelvic fin, the form of the first rays of the dorsal and pectoral fins in mature males, the relative alignment of the dorsal and ventral profiles of the postdorsal portion of the body, the position of the anus, and the depth of the body. DNA barcodes were generated for the holotype and paratype. An examination of other samples of Cetopsidium from the rio Branco system extends the range of $C$. pemon into the Ireng River system of Guyana.

Cetopsidium soniae, espécie nova, é descrita da bacia do rio Takutu, sudoeste da Guiana, na porção superior do rio Branco, bacia Amazônica. A nova espécie difere das demais espécies do gênero em detalhes de pigmentação, pelo comprimento da nadadeira pélvica, na forma dos primeiros raios das nadadeiras dorsal e peitoral em machos maduros, no relativo alinhamento dos perfis dorsal e ventral da região pós-dorsal do corpo, na posição do ânus, e na altura do corpo. Códigos de barra de DNA foram gerados para o holótipo e parátipo. O exame de outras amostras de Cetopsidium do sistema do rio Branco estende a distribuição de C. pemon até o sistema do rio Ireng na Guiana.

Key words: Taxonomy, New Catfish, Takutu River basin.

\section{Introduction}

The Neotropical catfishes of the subfamily Cetopsinae have a broad distribution throughout much of South America to both sides of the cordilleras of the Andes. Recent studies of the species-level taxonomy of the Cetopsinae (Oliveira $e t$ al., 2001; Vari et al., 2003, 2005) resulted in the description of 19 new species for a total of 37 species in the subfamily. That notable degree of previously undetected species diversity in conjunction with the major areas within the range of the Cetopsinae from which samples of the subfamily remain sparse or unknown makes it very likely that the species level understanding of the Cetopsinae remains far from complete. Exemplifying this situation is the genus Cetopsidium Vari et al., 2005, that underwent an increase from two to six recognized species in the last six years (Vari et al., 2003, 2005). Species of Cetopsidium are of relatively small body sizes and typically inhabit streams and smaller rivers in localities scattered across central and northern cis-Andean South America (Vari et al., 2005, fig. 2). Such habitats are by their nature often difficult to access or thoroughly sample (Vari \& Malabarba, 1998) and as would be expected, collecting efforts in those settings continue to yield numerous species previously unknown to science. Examination of a sample of Cetopsidium from the Takutu River system in the Rupununi region of southwestern Guyana revealed a previously unknown species of the genus that we describe herein.

\section{Material and Methods}

Institutional abbreviations are ANSP, Academy of Natural Sciences, Philadelphia; CSBD, Centre for the Study of Biological Diversity, University of Guyana, Georgetown; MHNG, Muséum d'histoire naturelle, Geneva; and USNM, National Museum of Natural History, Smithsonian Institution, Washington, D.C.

All measurements are straight-line distances between points with head length (HL) measured from the snout to the end of the fleshy gill cover. Interorbital width was taken as the shortest distance between the orbits, but is difficult to measure unambiguously. Size of examined specimens is

${ }^{1}$ Division of Fishes, Department of Vertebrate Zoology, MRC-159, National Museum of Natural History, PO Box 37012, Smithsonian Institution, Washington, D.C. 20013-7012. varir@si.edu

${ }^{2} 2944$ NE Couch Street, Portland, Oregon, 97232, U.S.A., and Research Associate, Department of Vertebrate Zoology, MRC-159, National Museum of Natural History, PO Box 37012, Smithsonian Institution, Washington, D.C. 20013-7012, U.S.A. carlferraris@comcast.net 
reported as standard length (SL). Radioopacity of the limited available sample of the new species because of the original fixative made it impossible to determine the number of preanal, precaudal, caudal, and total vertebrae. Counts of fin rays were from whole specimens. Because of the condition of the sample, we do not distinguish unbranched from branched rays other than in the case of the pelvic fin. The dorsal spinelet is not included in the count of rays for that fin. Specimens were sexed based on their possession of the sexually dimorphic features that are present in congeners. The range of values for meristic and morphometric features in the species is presented first, followed by the value for the holotype in square brackets. Tissue samples from the holotype and paratypes were preserved in $80 \%$ ethanol and stored at $-20^{\circ} \mathrm{C}$. Total genomic DNA was extracted with the DNeasy Tissue Kit (Qiagen) following the instructions of the manufacturer. The PCR amplifications of the 648-bp region of the cytochrome $c$ oxidase I (COI) mitochondrial gene required for DNA barcodes were carried out using the Taq PCR Core Kit (Qiagen). The primers used were: Fish-F15'-TCAACC AAC CAC AAA GAC ATT GGC AC-3' and Fish-R1 5'-TAG ACT TCT GGG TGG CCA AAG AAT CA-3'. The amplifications were performed in a total volume of $50 \mu \mathrm{l}$, containing $5 \mu \mathrm{l}$ of $10 \mathrm{x}$ reaction buffer, $1 \mu \mathrm{l}$ of dNTP mix at $10 \mu \mathrm{M}$ each, $1 \mu \mathrm{l}$ of each primer at $10 \mu \mathrm{M}, 0.2 \mu \mathrm{l}$ of Taq DNA Polymerase equivalent to 1 unit of Polymerase per tube, and $1 \mu \mathrm{l}$ of DNA. Cycles of amplification were programmed with the following the profile: (1) $3 \mathrm{~min}$. at $94^{\circ} \mathrm{C}$ (initial denaturing), (2) $35 \mathrm{sec}$. at $94^{\circ} \mathrm{C}$, (3) 30 sec. at $54^{\circ} \mathrm{C}$, (4) $50 \mathrm{sec}$. at $72^{\circ} \mathrm{C}$, and (5) $5 \mathrm{~min}$. at $72^{\circ} \mathrm{C}$ (final elongation). Steps 2 to 4 were repeated 39 times. PCR products were purified with the High Pure PCR Product Purification Kit (Roche). Sequencing reactions were performed with the Big Dye Terminator Cycle Sequencing Ready Reaction 3.1 Kit (Applied Biosystems) following instructions of the manufacturer, and were loaded on an automatic sequencer 3100Avant Genetic Analyzer (Applied Biosystems, Perkin-Elmer).

\section{Results \\ Cetopsidium soniae, new species Fig. 1}

Holotype. CSBD F1665; formerly MHNG 2652.014, in part, 30.9 mm, male, Guyana, Central Rupununi (Region 9), main channel of Manari River, Takutu River basin, along road between Lethem and Annai, near Lethem, 3²6.590’ N 5944.578’W, altitude 329 m, B. Allocock, G. King, J. I. Montoya-Burgos, R. Covain, A. Fort \& R. Daniels, 29 Oct 2004.

Paratype. MHNG 2652.014, 35.9 mm, female; collected with holotype.

Diagnosis. Cetopsidium soniae differs from its congeners in the posterior extent of the pelvic fin (falling distinctly short of the vent versus extending beyond the vent and reaching to the origin of the anal fin in C. minutum (Eigenmann, 1912), and reaching to or slightly beyond the anterior limit of the vent in C. ferreirai Vari, Ferraris \& de Pinna, 2005, C. morenoi (Fernández-Yépez, 1972), C. orientale (Vari, Ferraris \& Keith, 2003), and C. pemon Vari, Ferraris \& de Pinna, 2005, the position of the vent (proximate to the base of the anterior most anal-fin ray versus distinctly anterior to that location in C. roae Vari, Ferraris \& de Pinna, 2005), the form of the first rays of the dorsal and pectoral fins (with distal filaments present in males versus without such sexually-dimorphic filaments in $C$. ferreirai), the orientation of the dorsal and ventral profiles of the postdorsal portion of the body (converging posteriorly versus running in parallel in $C$. orientale), the distribution of dark pigmentation on the body (with pigmentation distributed across dorsal and lateral surfaces of body versus limited to middorsal region in C. ferreirai), the degree of dark pigmentation on the ventral surface of the lower jaw (with limited or no pigmentation versus with broad band of pigmentation in C. orientale), the form of the pigmentation on the head and body (chromatophores large and stellate versus small and round in C. minutum and C. pemon), the extent of the pigmentation on the dorsal fin (without any pigmentation or at most several small dark basal spots versus with distinct semicircular dark spot basally in C. morenoi, C. orientale, and C. pemon), the body depth (0.17-0.18 versus $0.14-0.15$ of SL in C. roae), and the form of the head in lateral view (triangular overall but relatively deep posteriorly versus more acutely triangular in C. minutum [see Vari et al., 2005, fig. 3]).

Description. Body moderately robust, somewhat compressed anteriorly and becomes progressively distinctly compressed posteriorly. Body depth at dorsal-fin origin approximately 0.17 0.18 [0.17] of SL, and approximately equal to distance from anterior margin of eye to rear of head. Lateral line on body unbranched, midlateral, incomplete, and extends from vertical through pectoral-fin base posteriorly to point within region from above middle of anal-fin base to slightly anterior to vertical through base of posterior most anal-fin ray. Dorsal profile of body straight from nape to dorsal-fin origin, slightly posteroventrally-aligned along base of dorsal fin and then straight from base of last dorsal-fin ray to caudal-fin base. Ventral profile of body slightly convex along abdomen, approximately straight and slightly converging posteriorly towards dorsal profile of body along anal-fin base. Caudalpeduncle depth greater than caudal-peduncle length.

Head relatively deep posteriorly, with lateral profile triangular overall but with bluntly pointed snout. Dorsal profile of head in male straight to slightly convex anteriorly, then straight to vertical located one orbital diameter posterior of rear margin of orbit, and finally broadly convex from that point to nape. Ventral profile of head variably convex. Head profile of female paratype deformed during preservation. Margin of snout in dorsal view broadly rounded. Postorbital margin of head slightly convex from dorsal view. Enlarged jaw musculature very evident on dorsal and lateral surfaces of postorbital portion of head.

Opercular membrane attached to isthmus only anterior of 
a
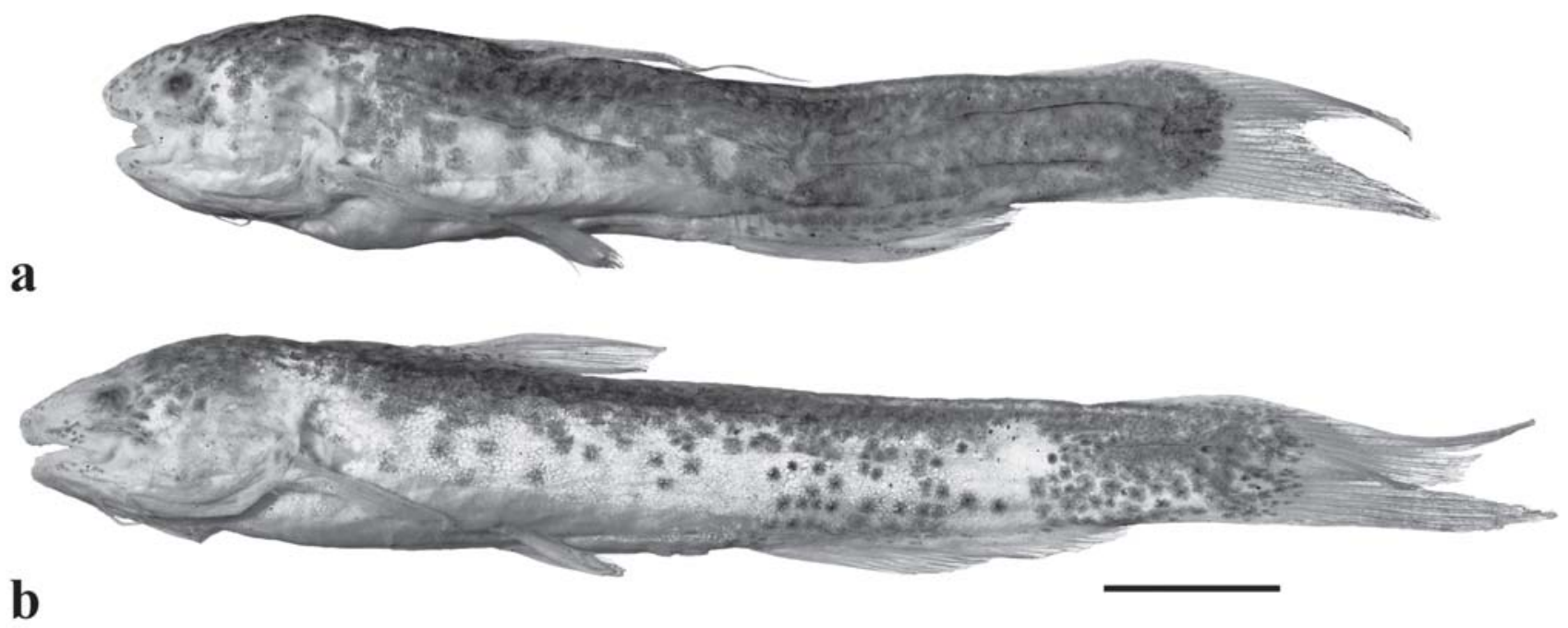

Fig. 1. Cetopsidium soniae: (a) CSBD F1665, holotype, 30.9 mm SL, male; (b) MHNG 2652.014, paratype, 35.9 mm SL, female; Guyana, Central Rupununi (Region 9), main channel of Manari River, Takutu River basin. Scale bar = 5 mm.

vertical through pectoral-fin insertion. Opercular opening moderately elongate; extends anteroventral of pectoral-fin insertion by distance approximately equal to one-third of head length and extends dorsal of pectoral-fin insertion by distance equal to horizontal extent of eye.

Eye situated on lateral surface of head; located dorsal to horizontal through pectoral-fin insertion; eye visible in dorsal view, but not in ventral view, of head. Middle of orbit at 0.36 [0.36] of HL. Eye diameter approximately one-third of length of snout. Interorbital width approximately equal to distance from tip of snout to point situated within region from middle of eye to posterior margin of orbit. Anterior narial opening circular, surrounded by short, anteriorly-directed, tubular rim of skin. Opening of anterior nares located slightly dorsal of horizontal that extends through maxillary-barbel origin and along horizontal that runs through ventral margin of orbit. Distance between anterior nares approximately equal to 1.5 orbital diameters. Posterior narial opening located on dorsal surface of head and situated dorsal to anterior one-third of orbit. Narial opening ovoid and bordered by flap of skin that nearly encircles aperture, but with small gap posteriorly; flap highest anterolaterally.

Mouth subterminal, very wide; its width 0.56 [0.56] of HL. Dorsal margin of lower jaw gently rounded, its posterior limit reaches to vertical through middle of orbit. Premaxillary tooth patch in form of gently arched band continuous across midline. Anterior margin of tooth patch convex and posterior margin concave and parallel to anterior margin. Teeth on premaxilla small, conical, sharply pointed, and uniform-sized across entire premaxilla, with three rows medially and two rows laterally. Palatal teeth in single arched row of 6 to 8 teeth, with distinct gap in series medially; gap approximately equal to one-half width of tooth patch on each side of palate. Palatal teeth conical, all of approximately uniform size, and with largest teeth approximately of same size as teeth on premaxilla. Dentary teeth comparable in shape to, and approximately same size as, premaxillary teeth, with three irregular rows medially that taper to one row laterally.

Maxillary barbel slender and extends posteriorly to point approximately one orbital diameter short of posterior margin of opercle. Barbel length approximately equal to length of postorbital portion of head, and approximately equal to twothirds of HL; barbel origin located ventral to anterior margin of orbit. Medial mental barbel slightly shorter than lateral mental barbel, with latter shorter than maxillary barbel. Medial mental-barbel origin located along vertical through rictus. Lateral mental-barbel origin situated slightly posterior of vertical through origin of medial mental barbel. Tips of adpressed mental barbels fall slightly short of, to barely beyond, opercular margin.

Dorsal-fin rays 6 [6]. Dorsal fin of moderate size, its base $0.35-0.36$ [0.36] of HL. Longest branched dorsal-fin ray equal in length to slightly less than two-thirds of HL. Dorsal-fin spinelet present, first dorsal-fin ray spinous for basal onehalf of length and flexible more distally, with well-developed distal filament in mature male. Distal margin of dorsal fin slightly convex, with first branched ray longest. Dorsal-fin origin located at $0.33-0.35$ [0.33] of SL and along vertical that extends through distal one-quarter of adpressed pectoral fin (leaving aside pectoral filament in male). Tip of adpressed dorsal fin in female reaches posteriorly to point slightly beyond tip of pelvic fin and slightly short of vertical through anterior margin of vent. Tip of distal filament of first ray in mature male reaches vertical through point approximately onethird length of anal-fin base from anal-fin origin. Last dorsal-fin ray with slight basal posterior membranous attachment to body.

Caudal fin deeply forked, symmetrical; tips of lobes rounded. Length of longest caudal-fin ray 2.25 [2.25] times 
length of middle rays.

Anal-fin rays 19-21 [21]. Anal-fin base moderately long. Anal-fin origin located distinctly posterior of middle of SL and approximately at middle of TL. Anal-fin margin nearly straight in female, but convex in mature male. Last anal-fin ray with slight membranous attachment to body.

Pelvic-fin rays i,5 [i,5]. Pelvic fin small; distal margin slightly convex with middle rays longest. Pelvic-fin insertion located anterior to middle of SL and slightly anterior of vertical through posterior limit of dorsal-fin base. Tip of adpressed pelvic fin extends to middle of SL but falls distinctly short of anterior margin of vent. Last pelvic-fin ray with membranous attachment to body along basal one-half of its length.

Pectoral-fin rays i,6 [i,6]. Pectoral fin moderately long, its length not including distal filament in male 0.53-0.54 [0.54] of HL. Pectoral-fin margin distinctly convex, with middle ray longest. First pectoral-fin ray spinous and slightly more than one-half length of first branched ray. Tip of first ray falling short of pelvic-fin origin in female, but prolonged as filament in mature male and reaching posteriorly to vertical running through point approximately at distal one-third of pelvic fin.

Coloration in alcohol. Overall ground coloration of head and body pale and overlain with rounded, large, brown chromatophores. Dark pigmentation on head well developed dorsally and in region posterior and posterodorsal to orbit. Scattered dark chromatophores present on lateral surface of snout, upper lip, and lower lip. Body distinctly darker dorsally, with expanded chromatophores in that region irregularly conjoined to form nearly uniform brown cast on portions of dorsal, dorsolateral and to varying degrees lateral surfaces of region posterior of vertical through insertion of anal fin. Dark pigmentation on body more pronounced in male. Ventral surface of body mostly pale other than for few scattered expanded chromatophores proximate to anal-fin origin.

Dorsal fin pale with some scattered dark chromatophores basally, but with that pigmentation not coalesced into distinct spot. Male with small flecks of dark pigmentation along length of spinous first ray; female with ray unpigmented. Anal fin pale with scattered dark chromatophores basally; chromatophores more numerous in male. Pelvic and pectoral fins pale. Caudal fin with dark chromatophores that form broad, posteriorly-convex band continuous with body pigmentation and overlying basal portions of caudal fin in male. Basal caudal-fin pigmentation less developed in female, with chromatophores in that specimen separated from each other and not extending as far distally onto fin rays.

Maxillary barbel with narrow, but distinct midlateral dark band on basal one-third to one-half and otherwise pale. Mental barbels pale overall, but with limited dark pigmentation basally in male.

Sexual dimorphism. The mature male of Cetopsidium soniae has an elongate filament extending from the tip of the first rays of the dorsal and pectoral fins. Such elaborations of these fins are characteristic of mature males of other species of Cetopsidium with the exception of $C$. ferreirai and occur in all adult males of all genera in the Cetopsinae other than for Denticetopsis Ferraris, 1996 (Vari et al., 2005). The male of Cetopsidium soniae has the anal-fin margin slightly convex rather than straight as in the female, another sexually dimorphic feature shared with mature males of the majority of species within the Cetopsinae with the exception of the members of Denticetopsis and some species of Cetopsis Spix \& Agassiz, 1829 (Vari et al., 2005; de Pinna et al., 2007).

Distribution. Cetopsidium soniae is known from the type locality in the Manari River, a tributary of the Takutu River in the western portions of the rio Branco system of the Amazon basin.

Habitat. At the time that the specimens were collected, the Manari River was approximately $1.5 \mathrm{~m}$ deep at the type locality with the substrate consisting of sand, gravel, and woody debris. Both the holotype and paratype were collected from holes in a large rock (S. Fisch-Muller, pers. comm.).

Etymology. The species name, soniae, is in honor of Dr. Sonia Fisch-Muller of the Muséum d'histoire naturelle, Geneva, who brought the species to our attention, has been of invaluable assistance to both authors with a number of projects over the years, and has contributed in myriad ways to our knowledge of South American catfishes.

Barcodes. GenBank accession numbers for the nucleotide sequences are GQ141710 and GQ141711.

Remarks. The combination of the presence of a dorsal fin retaining an ossified spinelet, the possession of pectoral and dorsal spines, and the termination of the lateral line posteriorly at a point above the base of the anal fin is unique to the species of Cetopsidium within the Cetopsidae (Vari et al., 2005). All of these features are present in C. soniae. Only one of these conditions, a lateral line that fails to extend past the vertical through the posterior terminus of the anal-fin base, was determined to be synapomorphic for the members of the genus under the phylogenetic hypothesis of relationships within the Cetopsidae proposed by de Pinna et al. (2007). The remaining external features that serve in combination to diagnose Cetopsidium (the presence of an ossified spinelet and possession of pectoral- and dorsal-fin spines) are symplesiomorphic within the Cetopsidae according to the results of that analysis. The additional synapomorphies identified by de Pinna et al. (2007) for Cetopsidium are internal features involving the first and third hypobranchials and the radials anterior to the anal-fin pterygiophores. The limited available sample of $C$. soniae prevented confirmation of these osteological features in the species.

Cetopsidium roae and C. pemon also occur somewhat proximate to the type locality of $C$. soniae in the upper rio Branco system. Cetopsidium roae of the Rupununi River basin of the upper Essequibo River system of Guyana differs 
from C. soniae in a number of features, most obviously in the overall form of the head and body and pigmentation (compare Fig. 1 with Vari et al., 2005, fig. 10). Vari et al. (2005) reported Cetopsidium pemon as a component of the ichthyofauna in the Brazilian portions of the rio Branco basin and as such it is the only member of the genus other than to $C$. soniae known from the rio Branco basin. As noted in the Diagnosis, C. soniae and $C$. pemon differ in the posterior extent of the pelvic fin, the form of the chromatophores on the head and body, and the extent of dark pigmentation at the base of the dorsal fin.

Examination of a lot of Cetopsidium from the Takutu River system (ANSP 180959; Guyana, Rupununi (Region 9), Ireng River, $04^{\circ} 01^{\prime} 10^{\prime \prime} \mathrm{N} 59^{\circ} 36^{\prime} 06^{\prime \prime} \mathrm{W}$ ), revealed it to be C. pemon. This is the first record of the species from a location in Guyana.

\section{Acknowledgements}

Research and museum visits associated with this publication were made possible through funding from the Herbert R. and Evelyn Axelrod Chair in Systematic Ichthyology, National Museum of Natural History, Smithsonian Institution, and the All Catfish Species Inventory, a program funded by the National Science Foundation (DEB0315963). Sonia Fisch-Muller (MHNG) brought the specimens that served as the basis of the description to our attention. T. Britt Griswold provided Fig. 1, Sandra J. Raredon (USNM) technical support for the project, and Mark Sabaj Pérez (ANSP) made possible a loan of other material from the type region. Barcode information was provided by Raphaël Covain (MHNG) who also secured the GenBank registration numbers.

\section{Literature Cited}

Oliveira, J. C. de, R. P. Vari \& C. J. Ferraris Jr. 2001. A new species of "whale catfish" (Siluriformes, Cetopsidae) from the western portions of the Amazon basin. Proceedings of the Biological Society of Washington, 114(3): 574-578.

de Pinna, M. C. C., C. J. Ferraris Jr. \& R. P. Vari. 2007. A phylogenetic study of the Neotropical catfish family Cetopsidae (Osteichthyes, Ostariophysi, Siluriformes) with a new classification. Zoological Journal of the Linnean Society, 150: 1-136.

Vari, R. P., C. J. Ferraris Jr. \& P. Keith. 2003. A new Pseudocetopsis species (Siluriformes, Cetopsidae) from Suriname and French Guiana. Proceedings of the Biological Society of Washington, 116(3): 692-698.

Vari, R. P., C. J. Ferraris Jr. \& M. C. C. de Pinna. 2005. The Neotropical whale catfishes (Siluriformes: Cetopsidae: Cetopsinae), a revisionary study. Neotropical Ichthyology, 3(2): 127-238.

Vari, R. P. \& L. R. Malabarba. 1998. Neotropical ichthyology: an overview. Pp. 1-11. In: Malabarba, L. R., R. E. Reis, R. P. Vari, Z. M. S. Lucena \& C. A. S. Lucena (Eds.). Phylogeny and Classification of Neotropical Fishes. Porto Alegre, Edipucrs, 603p.

Accepted July 23, 2009

Published September 30, 2009 